\title{
Characterization of Microalgae for Lipid Extraction
}

\author{
R. Kiruthika ${ }^{1^{*}}$ and S. Kamaraj ${ }^{2}$ \\ ${ }^{1}$ Department of Agricultural Engineering, RVS School of Engineering and Technology, \\ Dindigul - 05, Tamil Nadu, India \\ ${ }^{2}$ Department of Bio-energy, Agricultural Engineering College and Research Institute, \\ Tamil Nadu Agricultural University, Coimbatore - 641 003, Tamil Nadu, India \\ *Corresponding author
}

\section{A B S T R A C T}

\begin{tabular}{|l|}
\hline Ke y w o r d s \\
Biofuel, Microalgae, \\
Thermo gravimetric, \\
$\begin{array}{l}\text { Derivative thermo } \\
\text { gravimetric. }\end{array}$ \\
\hline Article Info \\
\hline $\begin{array}{l}\text { Accepted: } \\
\text { 12 October } 2017 \\
\text { Available Online: } \\
\text { 10 December } 2017\end{array}$
\end{tabular}

\section{Keywords}

Biofuel, Microalgae, gravimetric.

12 October 2017

10 December 2017
Biofuel production from algae using hydrothermal conversion technology is novel and the studies proved the feasibility of producing biofuel precursors such as biofuel to replace significant quantities of petrocrude used for the production of diesel, petrol and jet fuels. Three microalgal samples Botryococcus sp., Chlorella sp. and Tetradesmus wisconsinensis were selected and screened for fast growth and high oil content. Proximate composition of microalgal isolates was studied and the values of proximate composition such as moisture content, volatile matter, ash content and fixed carbon are resulted. Among all three algal strains, $T$. wisconsinensis is suitable for analysis, which results 3.7 per cent of moisture, 82.5 per cent of volatile, 2.4 per cent of ash and 11.1 percent of fixed carbon. The thermo gravimetric (TGA) and derivative thermo gravimetric (DTG) curves of the algae at heating rate of 40 in nitrogen revealed three stages of thermal decomposition for all the three microalgal isolates. The final weight loss from all the three isolates lies in the range of 53 to 74 per cent.

\section{Introduction}

Proximate analysis has been the most commonly used method for characterizing coal and other energy fuel sources (Garcia et al., 2012). The American Society for Testing and Materials (ASTM) developed a series of standards for this analysis. Ultimate analysis, also known as the element test, is the determination of carbon and hydrogen, as well as sulfur, nitrogen, and oxygen, in a material through their gaseous products in complete combustion. Both proximate and ultimate analyses can be done according to ASTM Standard E870-82. Determination of the elemental composition of whole biomass including various minerals in the ash is also helpful in understanding microalgae as a feedstock for biofuel production (Borah et al., 2009).

Thermo gravimetric analysis is used to investigate degradation behavior of the biomass, which is then used to develop kinetic models. There are many mathematical methods used to determine the reaction kinetics, but nearly all of them are based on the Arrhenius equation, $\left.k=A e^{\left({ }^{(} E\right.} / R T\right)$. Reported variables for the reaction are activation energy $E$ and pre-exponential 
factor, A. Accurate modeling of the degradation reactions of biomass is essential to understanding the behavior of a sample when heated inside a reactor or boiler. This knowledge is can be used to design the conversion system and to maximum the efficiency of the conversion process (Cai et al., 2008 and Gil et al., 2010).

Thermo gravimetric analysis is an emerging analytical technique that has been used to determine proximate biochemical compositions. TGA is based on continuous measurement of biomass weight loss versus temperature increase. Weight loss may arise from the evaporation of residual moisture or solvent or from the decomposition of organic matter at higher temperatures. If oxygen or air is used as the carrier gas then oxidation of organic matter also contributes to the weight loss (Tang et al., 2011; Chen et al., 2011). Although TGA is useful in determining volatile matter its accuracy remains approximate because TGA cannot precisely distinguish the components within a mixture. Nevertheless, TGA is still a widely used technique for characterizing biomass.

\section{Materials and Methods}

\section{Proximate analysis}

Proximate composition such as moisture content, volatile matter, ash content and fixed carbon content of algal biomass were determined by ASTM using procedures and details furnished below.

\section{Moisture content}

Using hot air oven, moisture content of the algal sample was determined. By oven method $3 \mathrm{~g}$ sample was taken in a petri dish and kept inside the oven at a temperature of $90^{\circ} \mathrm{C}$ for $24 \mathrm{~h}$. The moisture content was calculated by measuring weight of moisture evaporated from the sample $\left(\mathrm{W}_{2}\right)$ and the original sample weight $\left(\mathrm{W}_{1}\right)$. The formula is given below.

$$
\text { Moisture content }(\%)=\frac{W_{1}-W_{2}}{W_{1}} \times 100
$$

Where,

$\mathrm{W}_{1}=$ Initial weight of the algal sample, $\mathrm{g}$

$\mathrm{W}_{2}=$ Final weight of the algal sample, $\mathrm{g}$

\section{Volatile matter}

The volatile matter was determined using muffle furnace (ASTM D 3175-89). To measure the volatile content, known content of dried sample was taken in a closed crucible and kept inside the muffle furnace at $650^{\circ} \mathrm{C}$ for six minutes and again at $750^{\circ} \mathrm{C}$ for another six minutes. The loss in weight of the sample was found out and the per cent of volatile matter was calculated as

Volatile matter $(\%)=\frac{\text { Loss in weight of the algae biomass sample, } g}{\text { Weight of moisture free sample, } g} \times 100$

\section{Ash content}

The ash content of the sample was found out (ASTM D 3174-89) by taking a known quantity of dried sample in an open crucible and keeping it in a muffle furnace at about $750^{\circ} \mathrm{C}$ up to reaching a standard weight. The ratio between the remaining weight of materials in the crucible and the sample taken was the fraction of ash content of tested material.

$$
\text { Ash content }(\%)=\frac{\text { Weight of ash formed, } g}{\text { Weight of dried sample, } g} \times 100
$$

\section{Fixed carbon}

The fixed carbon of samples was calculated by subtracting the sum of ash content $(\%)$ and volatile matter (\%) from 100. The fixed carbon is the residue left after removing the 
volatile matter and the ash from the substance.

Fixed carbon $(\%)=100-[$ volatile matter $(\%)$ + ash content $(\%)]$

\section{Thermo Gravimetric Analysis (TGA)}

The biomass undergoes variety of reactions during thermal degradation process. Thermo Gravimetric Analysis (TGA), (Plate 3.6 - Q50, TA instruments, U.S.) was performed to determine changes in weight in relation to changes in temperature. The analysis relies on a high degree of precision in three measurements; weight, temperature and temperature change. A derivative weight loss curve was used to predict the point at which weight loss is more apparent. A computer is used to control the instrument. Analysis is carried out by raising the temperature gradually and plotting weight per cent against temperature. After the data are obtained, curve smoothing and other operations may be done such as to find the exact points of inflection. Thermo gravimetric analysis was carried out for the algal biomass at a heating rate of $10^{\circ} \mathrm{C} \mathrm{min}^{-1}$ for the degradation temperature of $1000^{\circ} \mathrm{C}$. A representative sample from laboratory culture, flocculated algal biomass and dried algal biomass were chosen for this analysis. Nitrogen was used as the purge gas with a flow rate of $60 \mathrm{~mL} \mathrm{~min}^{-1}$.

\section{Results and Discussion}

\section{Proximate composition of microalgae}

Proximate composition of microalgal biomass was determined as per the procedure presented and results are presented in Table 1.

Generally, thermal processes require a certain level of moisture content to achieve acceptable thermal conversion efficiency. Large-scale processing usually requires 8 per cent weight to 10 per cent weight moisture in the algal biomass. Too much moisture interferes with the conversion and drying (Brown, 2003). Table 1 illustrates that microalgae have relatively less moisture (average of $4.7 \%$ wt.) and thus assumed to be more suitable for direct thermal processing without the added cost of moisture removal.

\section{Thermo Gravimetric Analysis (TGA)}

Thermo gravimetric behaviour of Botryococcus sp. algal biomass at a heating rate of $10^{\circ} \mathrm{C} \mathrm{min}^{-1}$ in nitrogen atmosphere is shown as thermograms in Figure 1. The TGA and DG curves revealed that there were two stages in the process of thermal degradation. The first stage from $40^{\circ} \mathrm{C}$ to $280^{\circ} \mathrm{C}$ was characterized by a slight weight loss. During this stage, an initial slight weight loss of 7.591 per cent occurred between $40^{\circ} \mathrm{C}$ and $280^{\circ} \mathrm{C}$. In the second stage from $280^{\circ} \mathrm{C}$ to $500^{\circ} \mathrm{C}$ a major weight loss of 18.53 per cent was noticed and during the third stage $500^{\circ} \mathrm{C}$ to $1000^{\circ} \mathrm{C}$ a slow further loss of weight 5.88 per cent showed that the carbonaceous matters in the solid residue continuously decomposed at a very slow rate (Table 2).

As a result of whole process the final weight loss reached upto 32.01 per cent. From $40^{\circ} \mathrm{C}$ to $306.69^{\circ} \mathrm{C}$ the weight loss has been observed as 11.90 per cent. It concludes that the maximum weight loss was observed at the temperature of $306.69^{\circ} \mathrm{C}$.

Thermo gravimetric behaviour of Chlorella $s p$. isolate at a heating rate of $10^{\circ} \mathrm{C} \mathrm{min}{ }^{-1}$ in nitrogen atmosphere is shown as thermograms in Figure 2. The TGA and DG curves revealed that there were two stages in the process of thermal degradation. The first stage from $40^{\circ} \mathrm{C}$ to $270^{\circ} \mathrm{C}$ was characterized by a slight weight loss. During this stage, an initial slight weight loss of 15.85 per cent occurred between $40^{\circ} \mathrm{C}$ and $270^{\circ} \mathrm{C}$ (Table 3 ). 
Table.1 Proximate composition of microalgal isolates

\begin{tabular}{|c|l|c|c|c|c|}
\hline \multirow{2}{*}{$\begin{array}{c}\text { S. } \\
\text { No. }\end{array}$} & \multicolumn{1}{|c|}{ Algal isolates } & \multirow{2}{*}{$\begin{array}{c}\text { Moisture } \\
\text { content, \% }\end{array}$} & $\begin{array}{c}\text { Volatile } \\
\text { matter }\end{array}$ & $\begin{array}{c}\text { Ash } \\
\text { content }\end{array}$ & $\begin{array}{c}\text { Fixed } \\
\text { carbon }\end{array}$ \\
\hline 1. & Botryococcus sp. & $4.2 \pm 0.14$ & $80.8 \pm 0.02$ & $3.3 \pm 0.25$ & $11.5 \pm 0.41$ \\
\hline 2. & Chlorella sp. & $4.5 \pm 0.16$ & $79.7 \pm 0.12$ & $2.9 \pm 0.17$ & $12.8 \pm 0.37$ \\
\hline 3. & Tetradesmus wisconsinensis & $3.7 \pm 0.23$ & $82.5 \pm 0.27$ & $2.4 \pm 0.28$ & $11.1 \pm 0.28$ \\
\hline
\end{tabular}

\pm Standard error; each value is the mean of three replicated values.

Table.2 Thermal decomposition of Botryococcus sp. algal biomass at the heating rate of $10^{\circ} \mathrm{C} \mathrm{min}^{-1}$

\begin{tabular}{|c|cc|c|c|}
\hline \multirow{2}{*}{ S.No. } & \multirow{2}{*}{$\begin{array}{r}\text { Thermal decomposition of algal } \\
\text { biomass }\end{array}$} & & \multicolumn{2}{|c|}{ Dry weight (10 mg) } \\
\cline { 3 - 4 } & Stages & $\begin{array}{r}\text { Temperature range } \\
\left({ }^{\circ} \mathbf{C}\right)\end{array}$ & $\begin{array}{c}\text { Weight loss } \\
(\boldsymbol{\%})\end{array}$ \\
\hline 1. & Stage -1 & $40-280$ & 7.59 \\
\hline 2. & Stage -2 & $280-500$ & 18.53 \\
\hline 3. & Stage -3 & $500-1000$ & 5.88 \\
\hline
\end{tabular}

Table.3 Thermal decomposition of Chlorella sp. algal biomass at the heating rate of $10^{\circ} \mathrm{C} \mathrm{min}^{-1}$

\begin{tabular}{|c|c|c|c|}
\hline \multirow[b]{2}{*}{ S.No. } & \multirow{2}{*}{$\begin{array}{l}\text { Thermal decomposition of algal } \\
\text { biomass } \\
\text { Stages }\end{array}$} & \multicolumn{2}{|c|}{ Dry weight (10 mg) } \\
\hline & & $\begin{array}{c}\text { Temperature range } \\
\left({ }^{\circ} \mathbf{C}\right)\end{array}$ & $\begin{array}{l}\text { Weight loss } \\
(\%)\end{array}$ \\
\hline 1. & Stage -1 & $40-270$ & 15.85 \\
\hline 2. & Stage -2 & $270-500$ & 35.51 \\
\hline 3. & Stage -3 & $500-1000$ & 8.06 \\
\hline
\end{tabular}

Table.4 Thermal decomposition of Tetradesmus wisconsinensis algal biomass at the heating rate of $10^{\circ} \mathrm{C} \mathrm{min}^{-1}$

\begin{tabular}{|c|rr|c|c|}
\hline \multirow{2}{*}{ S.No. } & \multirow{2}{*}{$\begin{array}{r}\text { Thermal decomposition of algal } \\
\text { biomass }\end{array}$} & \multicolumn{2}{|c|}{ Dry weight (10 mg) } \\
\cline { 3 - 4 } & Stages & & Temperature range & $\begin{array}{c}\text { Weight loss } \\
(\boldsymbol{\%})\end{array}$ \\
\hline 1. & Stage -1 & $40-290$ & 15.83 \\
\hline 2. & Stage -2 & $290-500$ & 39.31 \\
\hline 3. & Stage -3 & $500-1000$ & 7.80 \\
\hline
\end{tabular}


Fig.1 Thermal behaviour of Botryococcus sp. pyrolyzed at $10^{\circ} \mathrm{C} \min ^{-1}$

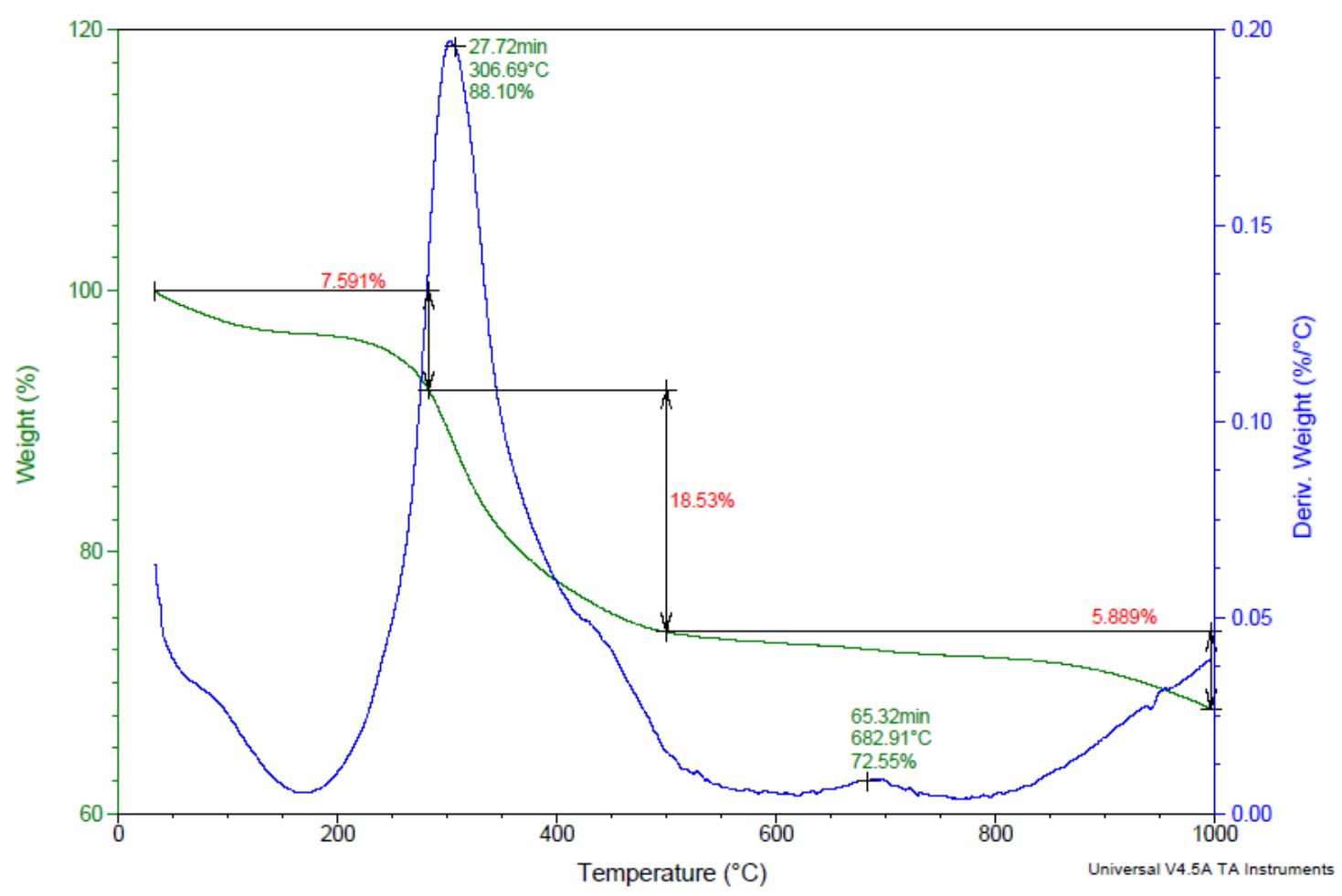

Fig.2 Thermal behaviour of Chlorella sp. pyrolyzed at $10^{\circ} \mathrm{C} \mathrm{min}^{-1}$

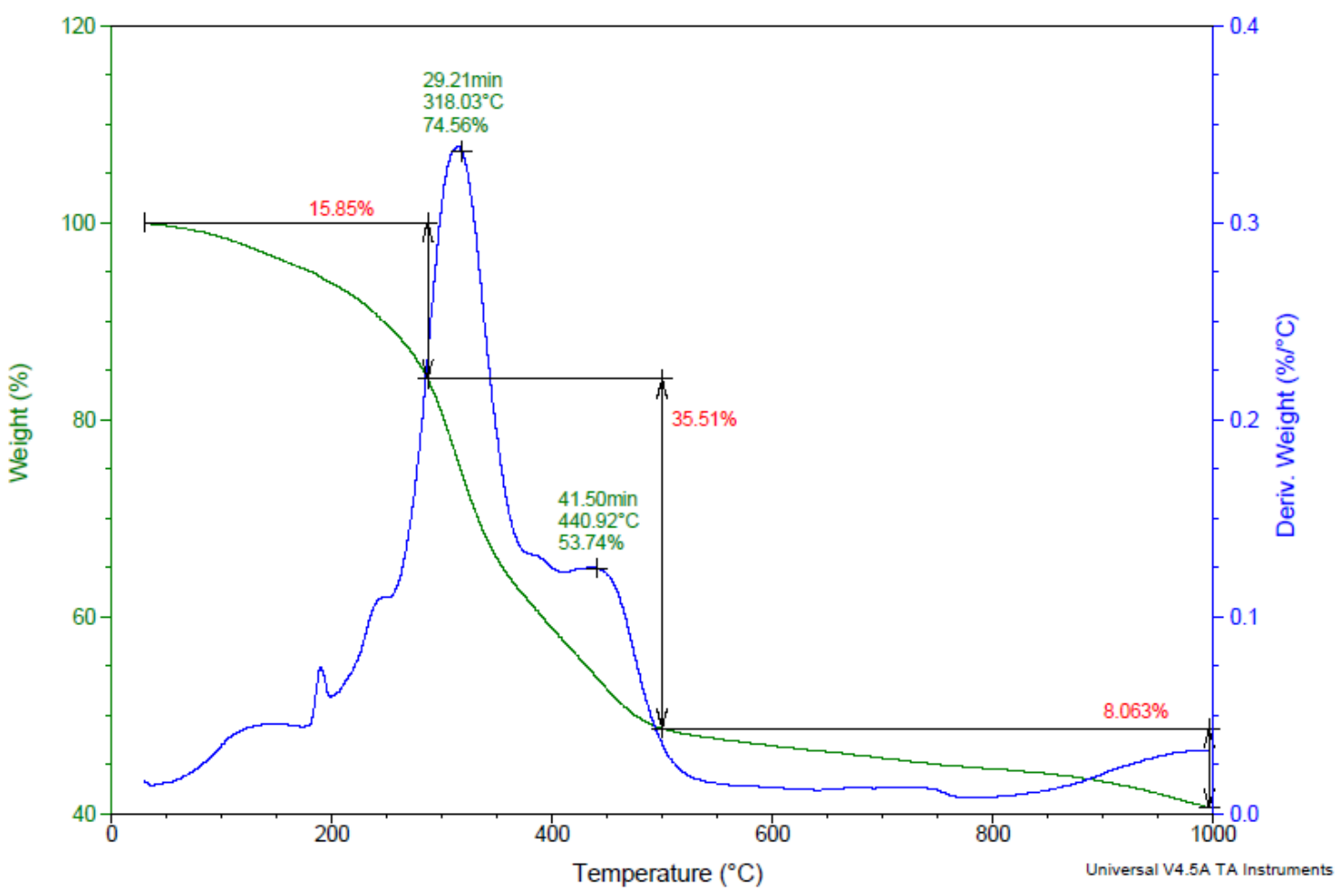


Fig.3 Thermal behaviour of Tetradesmus wisconsinensis pyrolyzed at $10^{\circ} \mathrm{C} \mathrm{min}^{-1}$

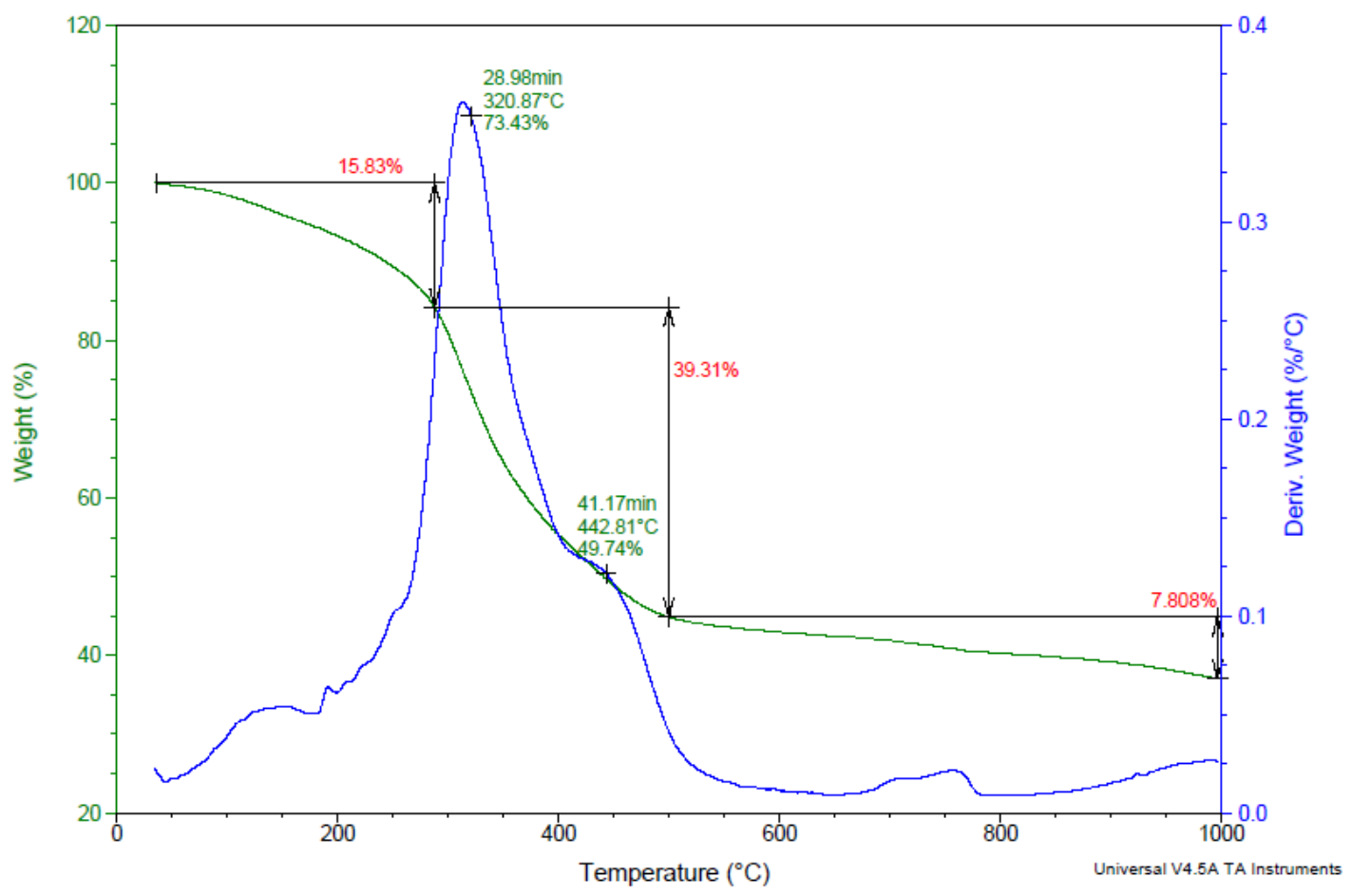

In the second stage from $270^{\circ} \mathrm{C}$ to $500^{\circ} \mathrm{C}$ a major weight loss of 35.51 per cent was noticed and during the third stage $500^{\circ} \mathrm{C}$ to $1000^{\circ} \mathrm{C}$ a slow further loss of weight 8.06 per cent showed that the carbonaceous matters in the solid residue continuously decomposed at a very slow rate. As a result of whole process the final weight loss reached upto 59.42 per cent. From $40^{\circ} \mathrm{C}$ to $318.03^{\circ} \mathrm{C}$ the weight loss has been observed as 25.44 per cent. It concludes that the maximum weight loss was observed at the temperature of $318.03^{\circ} \mathrm{C}$.

Thermo gravimetric behaviour of Tetradesmus wisconsinensis isolate at a heating rate of $10^{\circ} \mathrm{C} \mathrm{min}^{-1}$ in nitrogen atmosphere is shown as thermograms in Figure 3. The TGA and DG curves revealed that there were two stages in the process of thermal degradation. The first stage from $40^{\circ} \mathrm{C}$ to $290^{\circ} \mathrm{C}$ was characterized by a slight weight loss. During this stage, an initial slight weight loss of 15.83 per cent occurred between $40^{\circ} \mathrm{C}$ and $280^{\circ} \mathrm{C}$. In the second stage from $290^{\circ} \mathrm{C}$ to $500^{\circ} \mathrm{C}$ a major weight loss of 39.31 per cent was noticed and during the third stage $500^{\circ} \mathrm{C}$ to $1000^{\circ} \mathrm{C}$ a slow further loss of weight 7.80 per cent showed that the carbonaceous matters in the solid residue continuously decomposed at a very slow rate (Table 4). As a result of whole process the final weight loss reached upto 62.94 per cent. From $40^{\circ} \mathrm{C}$ to $320.87^{\circ} \mathrm{C}$ the weight loss has been observed as 26.57 per cent. It concludes that the maximum weight loss was observed at the temperature of $320.87^{\circ} \mathrm{C}$.

\section{References}

Borah, S., Barush, A., Das, A., and Borah, J. 2009. Determination of mineral content in commonly consumed leafy vegetables. Food Anal. Methods. 2(3): 226-230.

Brown, R. C. 2003. Biorenewable Resources: Engineering New Products from Agriculture. Ames, Iowa: Iowa State Press. 
Cai, J., Wang Y., Zhou, L. and Huang, Q. 2008. Thermogravimetric analysis and kinetics of coal/plastic blends during co-pyrolysis in nitrogen atmosphere. Fuel Process Technol.89:21-27.

Chen, C., Ma, X. and Liu, K. 2011. Thermogravimetric analysis of microalgae combustion under different oxygen supply concentrations. Appl. Energ. 88(9): 3189-3196.

García, R., Pizarro, C. Lavín, A. and Bueno, J. 2012. Characterization of Spanish biomass wastes for energy use.
Bioresour. Tech.103 (1): 249-258.

Gil, M.V., Casal, D., Pevida, C., Pis, J.J. and Rubiera, F. 2010. Thermal behaviour and kinetics of coal/biomass blends during co-combustion. Bioresour Technol. 101:5601-5608.

Tang, Y., Ma, X., and Lai, Z. 2011. Thermogravimetric analysis of the combustion of microalgae and microalgae blended with waste in $\mathrm{N}_{2} / \mathrm{O}_{2}$ and $\mathrm{CO}_{2} / \mathrm{O}_{2}$ atmospheres. Bioresour. Technol. 102(2): 1879-1885.

\section{How to cite this article:}

Kiruthika, R. and Kamaraj, S. 2017. Characterization of Microalgae for Lipid Extraction. Int.J.Curr.Microbiol.App.Sci. 6(12): 1295-1301. doi: https://doi.org/10.20546/ijcmas.2017.612.146 